\title{
DISTANCE MATHEMATICS LESSONS IN PRIMARY SCHOOL: SERVICES FOR CREATING INTERACTIVE EXERCISES
}

\author{
Svitlana Skvortsova ${ }^{1} \&$ Tetiana Britskan $^{2}$ \\ ${ }^{1}$ South Ukrainian National Pedagogical University named after K. Ushynsky, \\ Staroportofrankivs'ka 26, Odesa, 65020, Ukraine \\ ${ }^{2}$ Izmail State University of Humanities, Riepina12, Izmail, 68600, Ukraine \\ ${ }^{1}$ skvo08@i.ua, ORCID 0000-0003-4047-1301 \\ 2 britskan1994@gmail.com, ORCID 0000-0001-7277-4169
}

\begin{abstract}
The article is devoted to the research of the issue of using online services LearningApps, Google Classroom, Classtime, Classdojo for organizing distance learning of mathematics in primary school. According to the results of the scientific literature analysis, which are confirmed by the data of 'teachers' questionnaires, these services are the most common among primary school teachers in Ukraine. At the same time, working in these online services requires from the teacher a certain level of ICT competence, knowledge and the ability to apply algorithms for creating interactive exercises in individual templates and in certain services. Based on the analysis of the possibilities of these services for the creation of different types of mathematical tasks, the authors developed a content module, the purpose of which is to train future primary school teachers for creating interactive exercises in mathematics. The paper presents the results of experimental work with students majoring in 013 'Primary Education' of the South Ukrainian National Pedagogical University named after K.D. Ushynsky (Odesa, Ukraine) and Izmail State University of Humanities (Izmail, Ukraine). Having studied the module, 32\% of students showed a high level, 49\% - sufficient, 16\% - intermediate, and only 3\% low level of skills in working with the services LearningApps, Google Classroom, Classtime, Classdojo.
\end{abstract}

Keywords: ICT, online services, interactive tasks, mathematics, primary school.

\section{INTRODUCTION}

The issue of distance learning for school students has become relevant due to the quarantine restrictions caused by the Covid-19 pandemic. Ukrainian scientist N. Morse defines distance learning as an educational technology that enables communication between teachers and distant students using digital technologies (Morse, 
Buinytska, \& Varchenko-Trotsenko, 2016). Thus, scientists and teachers have intensified the search for online services to effectively organize their lessons.

In the scientific field, there are publications with an analysis of online services and recommendations for teachers on work with individual services (Skvortsova, Britskan, \& Haievets, 2020; Skvortsova \& Britskan, 2018; Skvortsova, Onopriienko, \& Britskan, 2019; Holguin-Alvarez, Rojas, Romero-Hermoza, Ledesma-Perez, \& Cruz-Montero, 2021; Kopniak, 2018; Zaitseva \& Muravieva, 2017; Izyumskaya, 2019; Novolokina, 2019).

\section{USING ONLINE SERVICES IN TEACHING MATHEMATICS TO PRIMARY SCHOOL STUDENTS}

Studying the organization of primary school 'students' education using digital learning resources (Khairova, Gabdullina, Gafurov, \& Valeeva, 2020), Himaletdinova R. and Aryabkina I. recommend using the services of Classroom, Picasaweb, Google Docs, Cacoo, Scratch Mit Edu (Himaletdinova \& Aryabkina, 2019). Kiricek K. and Torosyan D. offer the use of the services of Google Classroom, LearningApps, Online Test Pad (Kiricek \& Torosyan, 2021) in mathematics lesssons. For teaching mathematics, Novolokina I. suggests employing the educational online resources Classtime, Edpuzzle, Kahoot, Learning Apps, Liveworksheets, Mentimeter, Triventy, Wizer.me. (Novolokina, 2019); Perez W., Arenas A., Cariapaza D. point to the educational platform «Edmodo» (Perez, Arenas, Cariapaza, \& Brito, 2021). Herewith, special software tools are also used in primary school mathematics lessons, in particular www. delmat.info (Žilková, Partová, Gunčaga, Nemcová, Kopczyński, \& Zegzuła, 2019). For improving primary school 'students' computing skills, S. Skvortsova and R. Romanyshyn suggest using both interactive task banks and interactive calculation exercises created by teachers and involving the online services LearningApps, Liveworksheets, Wizer.me, as well as computing simulators in the educational online space Mexico (Skvortsova \& Romanyshyn, 2020).

The most common service among the discussed services is the service for creating interactive exercises - LearningApps. The works of Zaitseva S., Muravyova E., Izyumska O., Skvortsova S., Onopriienko O., Britskan T. (Zaitseva \& Muravieva, 2017; Izyumskay, 2019; Skvortsova \& Britskan, 2018; Skvortsova, Onopriienko, \& Britskan, 2020; Eyrikh, Bazhenov, Povkh, Alekseeva, Korosteleva, \& Soliman, 2020) are devoted to the research on the possibilities of using this service in primary school. Using the services of LearningApps and UmalGRA, Kiseleva O. developed a distance course in mathematics for primary school students, "Young smart men and smart women". The author proved that the creation of tasks in these services increases students' motivation and interest in learning and avoids the monotony of exercises (Kiseleva, 2018).

The work of S. Skvortsova and T. Britskan presents the generalized results of the online survey of primary school teachers of Ukraine on the use of these online services in mathematics lessons. It was revealed that the most popular services for creating interactive exercises are LearningApps, Google Classroom, Padlet, Classtime, Classdojo, H5P, Lino.it, Kahoot!. 
The research by Barbara Kołodziejczak shows that teachers are increasingly willing to use IT tools to support learning, but their knowledge of portals and ready-to-use learning environments is minimal (Kołodziejczak, 2019). At the same time, the study by Nataliia Morze, Eugenia Smyrnova-Trybulska and Mariia Boiko found a difference in the percentage between teachers of Ukraine and Poland in trying to take into account educational trends $-60.4 \%$ (Ukraine) and $31 \%$ (Poland), respectively, and those who do not take into consideration modern trends in education $-3.1 \%$ (Ukraine) and 0\% (Poland) (Morze, Smyrnova-Trybulska, \& Boiko, 2019).

Thus, training teachers to use online services to organize a distance lesson seems to be quite relevant. One of the services that allows for the creation of interactive content is H5P. Therefore, S. Skvortsova, T. Britskan and O. Onopriienko developed a technology of training future primary school teachers for work in the H5P service. As a result of experimental training, $83 \%$ of future primary school teachers have mastered the ability to create interactive exercises in mathematics using H5P (Skvortsova, Onopriienko, \& Britskan, 2019).

S. Skvortsova and T. Britskan developed an e-course for teachers, "Internet resources for creating educational and game content in mathematics for junior students". This course aims to acquaint teachers with the capabilities of the online services LearningApps, Google Classroom, Classtime, Classdojo.

The peculiarities of the content of the course and the organization of experimental training are revealed in the article by S. Skvortsova, T. Britskan and Ya. Haievets (Skvortsova, Britskan, \& Haievets, 2020). The authors present the results of a comparative analysis of the most common online services in three categories: 1) services for creating a virtual classroom, and its filling with interactive exercises and other educational content (LearningApps, Google Classroom, Classtime, Classdojo), 2) services for distance learning (Padlet, Lino it); 3) services for conducting a distance lesson in the form of a conference (Zoom, Skype, Microsoft Teams). The summarized results of the online survey of Ukrainian primary school teachers on using these online services in mathematics lessons are presented. Thus, we have identified the most popular online services among teachers - LearningApps, Google Classroom, Classtime, Classdojo, the need to train students - future primary school teachers for work in these online services is quite urgent.

The aim of the article is to analyze the possibilities of the online services LearningApps, Google Classroom, Classtime, Classdojo for creating interactive math problems for primary school, and to present the results of experimental training of future teachers - specifically, students majoring in the specialty of "Primary Education".

\section{A COMPARATIVE ANALYSIS OF THE ONLINE SERVICES LEARNINGAPPS, GOOGLE CLASSROOM, CLASSTIME, CLASSDOJO}

At the preparatory stage for the experimental training of future primary school teachers, we analyzed the possibilities of using the online services LearningApps, Google Classroom, Classtime, Classdojo; mainlyregarding the filling in of the lesson / course with educational materials and tasks. 
As a result of a comparative analysis of online services, we have determined the possibilities of each of them for the organization of mathematics education. It is convenient for the teacher in the LearningApps service to have a library of interactive tasks that they can use. The teacher can also create their own interactive exercises. To do this, Learning Apps offers the teacher a variety of templates: "Find a pair", "Classification", "Numeric line", "Simple ordering", "Free text answer", "Image fragments", "Quiz" and "Fill in the blanks". Teachers are also attracted to this service by means of presenting the conditions of tasks: in the form of text, images, sounded text, audio and video, as well as the ability to use different ways to add images, audio, and video to the tasks. Creating interactive exercises in mathematics, one often needs to download pictures with problems, short notes of problems, schematic drawings, diagrams. The Learning Apps service provides three ways to add images: 1) the use of images from Pixabay, Wikipedia Flickr; 2) select the image by copying the URL to it; 3) download images from your own computer.

Mathematical dictation is a common form of tasks in primary school, which involves presenting tasks in speech form. To select a certain element in the form of sounded text, one needs to print the text and choose the language in which the sounding will take place from the available list. The teacher can also write some cues to the sounded text for students. In the LearningApps service, ready-made audio can be added to tasks in two ways: 1) use the audio library from the YouTube archive; 2) use audio by specifying the video URL also from YouTube. Even in the case of linking to a video, only the audio portion will be displayed on the child's screen.

When creating a task in the LearningApps service, a video can be added to the task condition. To do this, the teacher should select the appropriate check mark in the "Pairs" section and: 1) use the video library from the YouTube archive; 2) use the video by typing in its URL from YouTube. It is very useful that creating a pair, elements of different formats can be combined. Thus, the teacher can create mathematical dictations with the help of the "Pairs" template and a combination of elements of different formats. The advantages of this form of mathematical dictation are that each student can listen to the task as many times as he/she needs and perform the tasks in any order (Skvortsova, Onopriienko, \& Britskan, 2020).

It is obvious that a teacher in teaching mathematics will use not one service, but several. We should note that the LearningApps service allows the integration with other services. Any exercise created in this service has links and a QR-code, with which it is very convenient to integrate them into other services, including Google Classroom and Padlet. It is also possible to insert interactive exercises into tasks in these services using the embeded code.

For the organization of distance learning mathematics for primary school students, instant testing, provided by interactive exercises, is of great importance. All templates of the Learning Apps service are interactive - based on them, tasks are created, which are automatically checked by the service. The variety of templates for interactive exercises and different options for presenting information in tasks significantly distinguish this service from others.

Unlike LearningApps, Google Classroom does not provide an opportunity to create interactive exercises - almost all templates for creating tasks imply an open answer. 
The only way to create a task that will be checked by the service automatically is Google Form. But, in this service, compared to LearningApps, it is possible to submit training materials that are not subject to verification and evaluation.

Open-ended tasks can be presented as a document downloaded from a computer or Google Drive or links to other content, including interactive exercises and YouTube videos. Students can be instructed on how to complete the task and what format they should send it to the teacher for review. The results of the tasks are sent to the teacher in the following ways: 1) a document is created and sent from a personal computer to Google Disk; 2) a text file is downloaded from a student's computer; 3) a photo of the completed in the notebook task is uploaded; 4) a screen with the results of interactive exercises is added; 5) an audio recording of the answers to the questions using a dictaphone in the gadget is recorded and then uploaded to Google Classroom. Using the Google Form application, the teacher can create a test task that will be checked by the service automatically. This task, according to the link code, can be imported into other services, including Padlet. In the Google Form application, the teacher can create questions in text format or give links to videos from YouTube, to which students can give short (template with short answers) or extended (template paragraph) answers.

It is worth noting that tasks created in Google Classroom cannot be imported into other services, but the teacher can provide a link to the training course created in this service. Classtime's opportunity to create interactive tasks, as well as that of Google Classroom, is limited. But, unlike Google Classroom, there are many more templates for creating interactive exercises - it's "One correct answer", "Several correct answers", "True/false", "Match", "Match (+1 answers in line)", "Set the order", "Text selection", "Select an area"; and the text template allows for the creation of open-ended tasks. Regardless of the choice of template, the teacher can add images, text, LaTeX formulas and videos from YouTube when creating each task. When preparing a task in the "Text" template, the student is expected to write a text answer. This task is not interactive, then the teacher checks the correctness of its performance. Using the Classtime service, the teacher has the opportunity to import questions from the Khan Academy and the EIT library.

Unlike Learning Apps and Classtime, the Classdojo service does not allow the teacher to create interactive tasks. Like Google Classroom, this service offers students openended tasks, and students can send their answers in a variety of formats - text, video, photos and drawings. But, unlike Google Classroom, in the Classdojo service, a student can send an answer only in the format chosen by the teacher when creating the task. Unlike the Learning Apps and Classtime services, the Classdojo service does not have its own task library. However, this service is of interest to students with an attractive e-journal and grading system, a means of calculating skills and helping the teacher organize the class's educational process, involving students, teachers, and parents. To create tasks in the Classdojo service, the teacher comes to the portfolio section and clicks to create tasks. The creation of tasks in this service and in Google Classroom is limited to open-ended tasks and only in the form of text. However, the teacher can add links to interactive tasks created with other services and other content, including videos from YouTube. 
Thus, we have discussed the possibility of creating interactive exercises in mathematics in the services LearningApps, Google Classroom, Classtime, Classdojo. The consideration of these services is the content of experimental training to prepare future primary school teachers for creating interactive exercises in mathematics.

\section{EXPERIMENTAL TRAINING OF FUTURE PRIMARY SCHOOL TEACHERS FOR CREATING INTERACTIVE EXERCISES}

\subsection{The aim, tasks and tools of the study}

The study aimed to teach future primary school teachers - students of pedagogical universities - to create interactive tasks in the services LearningApps, Google Classroom, Classtime, Classdojo.

The experimental study was conducted in the 2020-2021 academic year at the State Institution "South Ukrainian National Pedagogical University named after K.D. Ushynsky" (Ushynsky University) and Izmail State University of Humanities (Izmail University). At Ushynsky University, fourth-year students (17 students) mastered a separate module, "Using information technologies in teaching problem-solving" while studying the elective discipline, "Methods of teaching problem-solving", and at Izmail University, second-year students (20 students) studied the module, "ICT in teaching mathematics to primary school students" within the normative discipline, "Methods of teaching mathematics".

In the process of experimental research, the following tasks were solved: 1) development of the course / module program; 2) experimental training of students for work in the services LearningApps, Google Classroom, Classtime, Classdojo (lectures, workshops); 3) an analysis of the quality of students' interactive exercises created in these services by criteria (methodical, technical and aesthetic) and levels of development of interactive content; 4) determining the level of students' knowledge about the capabilities of the online services LearningApps, Google Classroom, Classtime, Classdojo and the opportunity to create interactive problems in mathematics in these services; 5) an analysis of the results of the students' - learners of the module survey on the motivation to create interactive exercises in mathematics and on the reflection of the acquired competence for further work.

\subsection{Results}

The first stage of the experimental study involved the development of a module of the elective discipline program, "Specifics of using ICT in teaching problem solving" at Ushynsky University, and supplementing the already developed discipline program with a module, "ICT in teaching mathematics to primary school students" at Izmail University. The purpose of these modules is to form in future teachers the ability to create interactive exercises and learning tasks in the services LearningApps, Google Classroom, Classtime, Classdojo. These skills were formed in students during 4 lectures and 4 practical classes. 
At the second stage of the experimental research, it was planned to hold lectures and practical classes with students according to the educational program of the disciplines. When mastering topic №1, students were offered a comparative description of the possibilities of creating a virtual class in the online services Google Classroom, Classtime, LearningApps, ClassDojo, the advantages and disadvantages of the individual services were identified, algorithms for creating a virtual class in each of them, filling it with tasks and inviting students to the virtual class were proposed, the possibilities of assessing tasks and recording the results of tasks in the electronic journal were also considered.

In the lessons on topic № 2, "Online services for creating interactive problems in mathematics", students gained theoretical knowledge and practical skills to create interactive exercises using various service templates. Thus, at the first lecture the peculiarities of creating educational tasks in Google Classroom and ClassDojo services were considered. In the context of considering the creation of learning tasks in Google Classroom, the aspect of creating test tasks using Google Forms was taken into account. The students applied the acquired knowledge in a practical lesson, creating their training courses in Google Classroom and ClassDojo services.

The next lecture discussed the peculiarities of creating interactive tasks using the services LearningApps and Classtime. We should note that acquaintance with all the templates took place by the demonstration of the service on the projector screen and the joint creation of tasks with the teacher, as well as by performing interactive tasks in mathematics in real time. Also, when getting acquainted with each template of the service, teachers provided an algorithm for creating a task in this template and mentioned which types of mathematical problems were advisable to use a particular template. Students created their own interactive problems in practical classes in compliance with mathematics textbooks, using the algorithms provided.

The third topic was a comparative analysis of the possibilities of these services for creating interactive exercises. While mastering this topic, students learned that tasks can be submitted in text format in all the services considered: LearningApps, Google Classroom, Classtime, Classdojo. One can submit tasks in image format in all the services mentioned above (LearningApps, Google Classroom, Classtime), except the service Classdojo. Tasks can be created only in the form of a table in Classtime, using the template "Match ( +1 answers per line)". In these services, one can add video and audio only from YouTube, which is not very convenient for teachers. Links to other content in such services as LearningApps, Google Classroom, Classdojo can be provided. Interactive tasks can be imported, including those created in LearningApps, into a service like Google Classroom.

Of great importance for the organization of distance learning are services that allow teachers to create interactive tasks that are automatically checked by the system. On the one hand, the student receives instant feedback after solving the problem, and on the other hand, the teacher, in a virtual journal, immediately sees the student's results, and if necessary, can review his/her work. Therefore, we compared the online services in view of the possibility of creating interactive exercises - tasks that are checked by the service and the available templates for creating interactive exercises. 
It should be noted that it is only LearningApps where all templates are interactive, in Classtime and Google Form only some of them are.

We compared the templates for creating interactive exercises based on the need of the creation of math problems. A lot of math problems involve entering answers - the results of arithmetic operations, the numerical values of the components of arithmetic operations, problem solving, and so on. For this type of task in the LearningApps service, the template "Free text response" can be used, and the condition can be provided in the form of text, images, sounded text, audio and video.

The creation of a similar task in Google Form is possible using the Short Answers template, where the answer contains only one word, or the Paragraph template, where the answer must be expanded. Tasks created in the template "With short answers" and "Paragraph", are checked by the teacher. A completely similar task can be created in the Classtime service using the "Text" template. This task involves recording the textual answer to the question in an expanded form, but it is not interactive, and the teacher checks its correctness.

The most attractive way to create interactive exercises in mathematics, especially oral problems, is a template that allows the student to enter the answers in the text of the problem. To do this, the LearningApps service has a "Fill in the blanks" template. There are two options - either the student will choose the answers from the list or enter them. The task condition can be submitted as text, image, audio or video.

If the type of task is chosen in LearningApps where the student will fill in the blanks by selecting them from the drop-down list, a similar task can be created in Google Form using the "Drop-down list" template. The Classtime service has a "Text selection" template, which assumes that students must choose the correct answer from the proposed text options.

The correct answer to fill in the blanks can be created in other templates. Thus, the Learning Apps service has an "Image fragments" template. To create an interactive exercise, tasks should be added in the form of an image, certain fragments of the image in which the gaps are to be filled must be marked with certain markers. It is worth noting that the markers that indicate gaps in the image can be selected in different colours, which reduces the number of answer options. Answer elements can be represented as text, images, sounded text, audio and video.

It should be noted that a similar task cannot be created in Google Form; whereas in the Classtime service one can use the "Select an area" template. Here, students must choose the correct answer from the suggested options, which are presented exclusively in the image format, by clicking on the appropriate fragment of the image. Mathematical interactive exercises are mostly created in templates such as "Free text answer" and "Fill in the blanks". At the same time, the possibility of forming pairs is of some interest. To create an interactive exercise using the "Find a pair" template, a Learning Apps user must create a pair by specifying two elements that match each other. The pair element can be represented as text, image, sounded text, audio and video. It is convenient that by creating a pair, one can combine elements of different formats, as well as the fact that three extra elements that will not have pairs can be added. Then we create certain settings: the pairs created on the child's screen will disappear instantly or one must first create all the pairs, and only then click on check. 
If in LearningApps pairs are formed by dragging, in Google Form and Classtime the pair can be considered as the intersection of a row and a column of the table. Thus, a similar task can be created in Google Form using the "Answer Options Table" template, where the student seems to find the answer to a certain question by marking the intersection of the task / question row and the column - answer options. Also, a similar task, but with a few correct answers, can be created using the "Grid of flags" template, where there can be two marks in one line. In the Classtime service, there is also an opportunity to present the task in the form of a table: the student chooses the task and the correct answer is marked. In this service, it is possible to create tasks with one or several correct answers, but another template - "Match $(+1$ answers per line)" must be chosen. Despite the possibility of making pairs in the form of a table in the services of Google Form and Classtime, we believe that the use of such tasks in primary school is impractical.

To create interactive tasks, it is sometimes advisable not to form pairs, but to drag the task element to a specific area, thus carrying out the classification. To create an interactive exercise in the LearningApps service using the "Classification" template, the service user must create 2-4 groups - classes and upload elements to each of them. They can specify a group name using text or images. The elements of each group can be represented in the form of text, image, sounded text, audio and video, and the maximum number of elements of one group should not exceed 10, and each group may have a different number of elements. Next, we make some adjustments: and the grouped items will appear gradually or immediately.

A similar task can be created in Google Form using the "Flags" template, where each task will contain several correct answers, and the student must mark them with flags. In Classtime, one can create a similar task in the "True/false" template, which allows the teacher to choose one of two options - true/false - for each question. Since there are only two answer options, the probability that the student can randomly choose the correct answer is quite high.

Many math problems involve restoring a certain order of numbers, geometric shapes, and so on. To do this, one can use the "Simple ordering" template in the LearningApps service. The task element can be represented in the form of text, image, sounded text, audio and video.

A similar task can be created in Google Form using the Linear Scale template, where students need to answer questions by selecting a specific number on the scale (1 to 10). A similar template is available in the Classtime service - "Set the order". But, unlike LearningApps, these elements can only be presented in text format.

A certain part of math problems in mathematics textbooks by S. Skvortsova and O. Onopriienko, which are valid in Ukraine, involves the selection of questions to the condition of the problem, and vice versa, a schematic drawing to the problem, or an analysis scheme to the text of the problem. Such tasks can be created in the LearningApps service using the "Quiz" template. The task condition and answers can be represented as text, images, sounded text, audio and video in this template. Questions with one correct answer or several answers can also be created.

In Google Form, quizzes can be created in the form of tests, but only in text form with one correct answer (template "3 answer options"), or with several correct an- 
swers (template "Flags"). In the Classtime service, test tasks can also be created using the template "One free answer" and "Several correct answers". But, unlike Google Form, in Classtime, both tasks and answer options are allowed by the service to be submitted in the form of text or images.

The third stage of the experimental study involved an analysis of the quality of students' interactive exercises created in the services LearningApps, Google Classroom, Classtime, Classdojo by certain criteria and levels.

Students' performance of individual projects was assessed according to methodological, technical and aesthetic criteria, and the following levels: low, intermediate, sufficient and high, which are described in detail in the article (Skvortsova, \& Britskan, 2018).

At the fourth stage of the study, the results of students' work were analyzed and the following results were obtained (figure 1): almost all students (97\%) mastered the knowledge and skills to create interactive exercises in these services, only $3 \%$ of students showed low mastery of these services. This $3 \%$ of students missed classes and did not show a desire to individually and independently acquire the knowledge and skills necessary for creating the interactive exercises.

At the fifth stage of the experimental research it was planned to conduct an anonymous survey of students - learners of the module - on their motivation to create interactive exercises in mathematics. According to the results of the survey, the developed module, "Specifics of using ICT in teaching problem solving" and "ICT in teaching mathematics to primary school students" interested students (97\%) and motivated them to continue working with online services in their future professional activity.

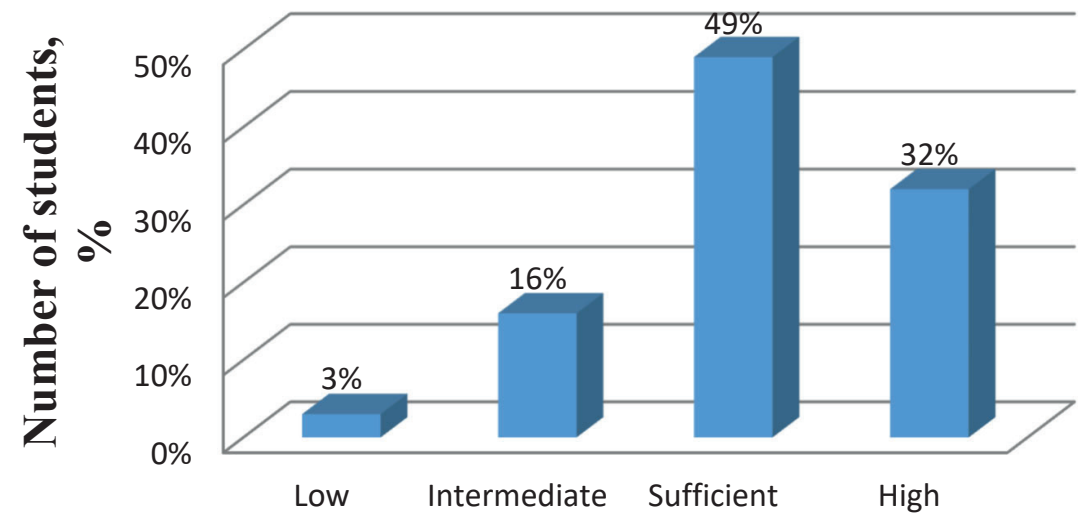

F i g u re 1. Results of assessing students' individual projects

S ource: Own work.

\section{CONCLUSIONS}

We studied the most popular online services for creating interactive exercises among Ukrainian primary school teachers- LearningApps, Google Classroom, Classtime, Classdojo and discussed the advantages and disadvantages of each of them for creating interactive exercises in mathematics. We asserted that the LearningApps service 
gives the teacher more opportunities to organize mathematics education, which allows them to create almost all types of interactive math problems. This service offers a variety of templates, a variety of forms of task presentation, and options for setting up a task for the student. But, unfortunately, Learning Apps has recently removed the opportunity to create a virtual classroom, and therefore, an e-journal. The options of a Virtual classroom and e-journal are available in Google Classroom, Classtime, Classdojo, but they provide limited opportunities to create interactive exercises or no opportunities.

During the experimental learning of the modules, "Specifics of using ICT in teaching problem solving" (Ushynsky University) and "ICT in teaching mathematics to primary school students" (Izmail University), students - future primary school teachers, using four topics were presented with the advantages and disadvantages of these services for creating math problems of different kinds. It was pointed out which templates are the most appropriate for the organization of oral numeracy, mathematical dictation, work on math problems, work with geometric material, etc.

The paper presented the results of the experimental training of future teachers - students of specialty 013 "Primary Education", during which they learned - according to the purpose of the mathematical task - to select the appropriate service and template and create an interactive service exercise using the algorithms provided. The complexes of the interactive exercises created by the students in the services LearningApps, Google Classroom, Classtime were assessed according to the criteria that determined the methodological expediency of choosing a template and the methodical literacy of task development, as well as the technical level of task development and aesthetics of task presentation. According to these criteria, the levels of students' mastery of the skills of creating interactive tasks in the services LearningApps, Google Classroom, Classtime were determined as low, intermediate, sufficient and high (Skvortsova, Britskan, 2018). A low level presupposed the available fragmentary knowledge and skills to create interactive tasks; the student can arrange the work of school students in the service on ready-made interactive content, but has difficulty in monitoring the process of solving interactive tasks and assessing the results of students' achievements. The results of experimental training show that $3 \%$ of the students have acquired a low level of mastering these services. The intermediate level indicates that the student has some theoretical knowledge about the service and is able to create their own exercise in the model, but has difficulty setting up the service when creating their own interactive content. $16 \%$ of the students reached this level. A sufficient level demonstrates that the user is aware of the service's peculiarities and can create standard tasks using images and has the knowledge and skills to configure the service for school students and assess their results. The results of the examination of students' works prove that the majority, in particular, $49 \%$ of students have achieved a sufficient level of mastering of these online services. A high level shows that the student's knowledge is profound, strong and systemic; the student is able to create interactive content and edit their own tasks depending on the needs of the lesson, to organize the work of school students with a series of educational tasks and the further assessment of students' academic achievements. $32 \%$ of the students reached this level. 
The results of the experimental training prove the effectiveness of the modules, "Specifics of using ICT in teaching problem solving" and "ICT in teaching mathematics to primary school students" in the educational process to apply the acquired skills in further professional activity in teaching mathematics to primary school students. Further research could be focused on expanding the range of online services for training future primary school teachers.

\section{REFERENCES}

Eyrikh, N., B a zh enov, R., Povkh, I., A lekseeva, L., Korosteleva, I., \& Soli man, K. (Ed.) (2020). Experience in interactive service, computer games and specialized software applied in teaching mathematics. Proceedings from the $35^{\text {th }}$ International-BusinessInformation-Management-Association Conference. Paphos: Seville, Spain. ISBN 978-09998551-4-0.

Hi ma let dinova, K. \& A ryabkina, I. (2019). Yspolzovanye sotsyalnykh servysov web 2.0 dlia razvytyia yntellektualnoho y tvorcheskoho potentsyala mladshykh shkolnykov. The era of science, 17, 110-114. https://doi.org/10.24411/2409-3203-2018-11725.

Holgu in-Alvarez, J., Rojas, M., Romero-Hermoza, R., Ledesma-Perez, F., Cruz - M o nt e r o, J. (2021). Digital competences and resilience: a theoretical review focused on teachers. Apuntes Universitarios, 11(4), 269-295. https://doi.org/10.17162/au.v11 i4.773.

I z y u m sk a y a, E. (2019). Ispol'zovanie servisa Learning Apps dlya sozdaniya interaktivnyh zadanij v nachal'noj shkole. Proceedings from the X All-Russian Scientific and Practical Conference Pedagogical. Paphos: Perm State Humanitarian Pedagogical University. ISBN 978-5-85219-035-2.

Khairova, I., Gabdullina E., Gafurov, I., \& Valeeva, R. (Eds.) (2020). The use of digital resources in the implementation of individual educational route of primary school students. Proceedings from the $6^{\text {th }}$ International Forum of Teacher Education. Paphos: Kazan Federal University. https://doi.org/10.3897/ap.2.e0989.

Kir ic ek, K. \& Tor o sy a n, D. (2021). Primenenie cifrovyh servisov na urokah matematiki $\mathrm{v}$ nachal'noj shkole. Bulletin of the Belgorod Institute for the Development of Education, 8, 1(19), 57-64. ISSN 2410-0366.

K i s e le va, O. (2018). Ispol'zovanie elektronnyh obrazovatel'nyh resursov seti Internet dlya razvitiya poznavatel'nyh sposobnostej mladshih shkol'nikov. Proceedings from the International Network Scientific and Practical Conference Actual Issues And Problems Of Using Online Courses In The Modern Digital Educational Environment. Paphos: Committee of Education, Science and Youth Policy of the Volgograd Region. ISBN 978-598926-194-9.

Kołodzi ejczak, B. (2019). The use of portals and learning environments in non-academic teaching. In E. S m y r n ov a - Tr y b u ls k a (Ed.). E-learning and STEM Education. Seria on E-learning. Vol. 11 (pp. 263-275). STUDIO NOA for University of Silesia. https:// doi.org/10.34916/el.2019.11.17.

Ko p n i ak, N. (2018). The use of interactive multimedia worksheets at higher education institution. Information technologies and learning tools, 63(1), 116-129. https://doi.org/10. 33407/itlt.v63i1.1887. 
Morze, N., B u inytska, O., \& Varchenko-Trotse n ko, L. (2016). Stvorennia suchasnoho elektronnoho navchalnoho courseu v systemi MOODLE. Kamianets-Podilskyi: PP Buinytska, O. ISBN 978-617-608-064-0.

Morze, N., S myrnova-Trybulska, E., \& B oiko, M. (2019). The impact of educational trends on the digital competence of students in Ukraine and Poland. In E. SmyrnovaTrybulska (Ed.). E-learning and STEM Education. Series on E-learning. Vol. 11 (pp. 366379). STUDIO NOA for University of Silesia. https://doi.org/10.34916/el.2019.11.23.

Novolok in a, I. (2019). Obzor obrazovatel'nyh onlajn-resursov dlya obucheniya matematike. Proceedings from the Collection of scientific articles Pedagogy today: tradition and innovation. Paphos: Scientific Publishing Center Absolute, Volgograd. ISBN 978-5-6042 843-7-7.

Perez, W., Arenas, A., Cariapaza, D., \& Brito, C. (Ed.) (2021). «Edmodo, generation $\mathrm{Z}$ and mathematics» significant in high school in Peru. Proceedings from the $5^{\text {th }}$ IEEE World Conference on Engineering Education. Paphos: University Galileo. https:/doi.org/ EDUNINE51952.2021.9429138.

Skvortsova, S. \& Britskan, T. (2018). Training for future primary school teachers in using service learning apps teaching mathematics. International Journal of Research in E-learning (IJREL), 4(1), 59-77. https://doi.org/10.31261/IJREL.2018.4.1.05.

Skvortsova, S., B ritska n, T., \& Ha i evet s, Y. (2020). E-course "Internet resources for creating mathematical learning and game content for primary school children". In E. S m y r nova-Trybuls ka (Ed.). Innovative Educational Technologies, Tools and Methods for E-learning. Series on E-learning. Vol. 12 (pp. 65-76). STUDIO NOA for University of Silesia. https://doi.org/10.34916/el.2020.12.06.

Skvortsova, S., O n op ri i en ko, O., \& Brits ka n, T. (2019). Training for future primary school teachers in using service H5P teaching mathematics. In E. Smyrnova-Trybulska (Ed.). E-learning and STEM Education. Series on E-learning. Vol. 11 (pp. 277-294). STUDIO NOA for University of Silesia. https://doi.org/10.34916/el.2019.11.18.

Skvort sova, S. \& Ro m a n y h y n, R. (2020). Use of online simulators for the formation of primary school leaners' computing skills. In E. S m y r n ova-Trybuls ka (Ed.). Innovative Educational Technologies, Tools and Methods for E-learning. Series on E-learning. Vol. 12 (pp. 207-219). STUDIO NOA for University of Silesia. https://doi.org/10.34916/ el.2020.12.18.

Zaitseva, S. \& Muravieva, E. (2017). Vozmozhnosti learning apps v organizacii uchebnogo processa nachal'noj shkoly. Proceedings from the International Scientific and Practical Conference Modern educational Web-technologies in the system of school and vocational training. Paphos: Arzamas Branch of the Federal State Autonomous Educational Institution. ISBN 978-5-9909905-8-6.

Ži l ková, K., P a r tová, E., G u n ča ga, J., N e m cová, J., Ko p c z y ń ski, T., \& Z e g zu ła, D. (2019). Development of geometrical thinking via educational software by pupils of elementary school. In E. S m y r n ov a - Tr y b u l s k a (Ed.). E-learning and STEM Education. Series on E-learning. Vol. 11 (pp. 483-501). STUDIO NOA for University of Silesia. https://doi.org/10.34916/el.2019.11.31. 